\title{
The Government Irrigation Project at Roosevelt Dam, Salt River, Arizona.
}

\author{
By Prof. Oscar C. S. Carter.
}

Arizona has two well marked physiographic divisions; there is a high plateau comprising the northern half of the State which is from 4000 to 8000 feet above tide. The southern half of the State is a low desert area which, however, is mountainous in the eastern part. An escarpment or wall separates these two parts of the State. This escarpment enters from Utah on the north and trends from the northwest to the southeast; it is the southern border or edge of the Colorado Plateau, which is named after the Colorado River, which has cut a gorge for 200 miles through this plateau, which is from 4000 to 6500 feet in depth. This is known as the greatest scenic wonder in the world-the Grand Cañon of the Colorado River.

The high parts of this plateau in the north are more than a mile higher than the low desert in the south. It is this low country that is to be irrigated. It is out of the question to irrigate the high plateau country, because the Colorado flows through the Grand Cañon, which is so deep that the water could not be pumped from it and the prospects for artesian water on this high plateau are not encouraging.

The student of a quarter of a century or more ago had a very vague and erroneous idea of a desert, and if we examine the textbooks of that time we will not wonder much at these strange conceptions of our childhood. A low and level expanse of sand, whirling in columns and drifting in heaps might describe limited areas of the African deserts but could have no reference to the deserts along the Mexican boundary line, the Yuma Desert, the Colorado Desert, Death Valley Desert, or the deserts of Nevada. Great mountain ranges with serrated crests gaunt and forbidding, enormous lava flows with rough and jagged surfaces. The great Vor. CLXIII. No. 976 
variety of cacti with their beautiful but scentless flowers. Cacti which vary in height from the low egg-shaped forms but a couple of inches in height, capped with a yellow flower, which one sees on the Colorado Plateau, to the enormous cereus giganteus or suguarro of the Mexicans which rears its candelabra-like arms thirty and forty feet above the desert floor, reminding one of the flora of a past Geological Age. The sage, the Mexican greasewood, the mesquite, the occasional dense growth of chapparal took no part in the description of a desert in our childhood days. In an article on Death Valley by the author (see JournaI. of Franklin Institute, Sept., I9O2,) the reference is made to several interesting and valuable articles on the deserts of the United States. Notably, one by Captain Gaillard, of the Mexican Boundary Commission, on "The Perils and Wonders of a True Desert." Another valuable and more recent article on the “American Desert," by Robert T. Hill, formerly Geologist of Texas. These articles give one a clear conception of our deserts as they are. Let one read the Report of the Mexican Boundary Commission, which is handsomely illustrated and is a valuable document especially from a geographic standpoint. It treats of a region most of which was practically unknown and new country before traversed by the engineers of the commission and which does not contain as many inhabitants as some of our rural towns. Some of the deserts along this boundary, like the Yuma and Colorado Deserts, are veritable Saharas and are even hotter and more arid. The Colorado Desert is named from the River of that name which flows through it and empties into the Gulf of California. This river could not exist in this region were it not fed by the snows and lakes of the Rockies, and yet these deserts bloom like a garden when irrigated; the soil is fertile, no plant growth has ever exhausted it; the only thing wanted is water, when it will produce five crops of alfalfa grass in a year. When the Government irrigation projects are finished the United States will take the lead as the foremost country in the world where irrigation is practiced on a gigantic scale. It must not be thought for one instant, however, that irrigation was not practiced extensively here before the Government Reclamation Service was esablished. Major J. W. Powell, formerly Director of the U. S. Geological Survey, in his statement before the Committee of Irrigation of the House of Representatives in I890, stated: $\mathrm{Mr}$. 
Chairman, I have prepared a table by States and Territories of the land irrigated.

IRRIGATED AREAS TOTALS.

States.

Arizona

California

Colorado ....................

Idaho

Montana

Nevada

New Mexico.................. $1,360,000$

Oregon $\ldots \ldots \ldots \ldots \ldots \ldots \ldots \ldots$ I9 1,000

Utah $\ldots \ldots \ldots \ldots \ldots \ldots \ldots \ldots \ldots$

Wyoming

Total
Under ditches constructed or projected. Acres. 455,600 740,000$$
\text { I } 227,819
$$

$$
\begin{gathered}
\text { Irrigated and } \\
\text { under ditch. } \\
\text { Acres. } \\
\text { I75,000 } \\
3,000,000 \\
2,000,000 \\
400,000 \\
348,000 \\
75,000 \\
638,000 \\
119,000 \\
802,000 \\
500,000 \\
\hline 8,057,000
\end{gathered}
$$

\begin{tabular}{|c|c|}
\hline $\begin{array}{l}\text { Length. } \\
\text { Miles. }\end{array}$ & $\begin{array}{r}\text { Length. } \\
\text { Miles. }\end{array}$ \\
\hline Arizona . & Utah \\
\hline Grand & Farmers \\
\hline Maricopa $\ldots \ldots \ldots \ldots \ldots \ldots \ldots$. 4 & Highland \\
\hline Salt River Valley............. 8 & Dutch Ditch........... \\
\hline San Francisco............ & Monterey $\ldots \ldots \ldots \ldots \ldots$ \\
\hline Tempie $\ldots \ldots \ldots \ldots \ldots \ldots \ldots \ldots \ldots$ & Griffin .. \\
\hline
\end{tabular}

He states in a foot note, however, that the figures are not comparable among themselves as they are derived from many sources and by various persons, each having different purposes and ideas as to what constitutes irrigation. Mr. F. H. Newell, Chief of the Reclamation Surface States, in an article on the Hydrography of the Arid Regions ( I 2th Annual Report U. S. Geological Survey, Part II, page 3 I 2, ) that as far back as 1889 the following canals were reported in the Salt River Valley in Arizona, the water being taken from the Salt River:

It must be borne in mind that these 175 miles of canals are in Maricopa county alone and the water is drawn from the Salt River, which is to supply the water for the enormous Roosevelt dam, 285 feet high. The Gila River in Yuma county, into which the Salt River empties, furnished water in 1889 for more than I 8 miles of irrigating canals. 


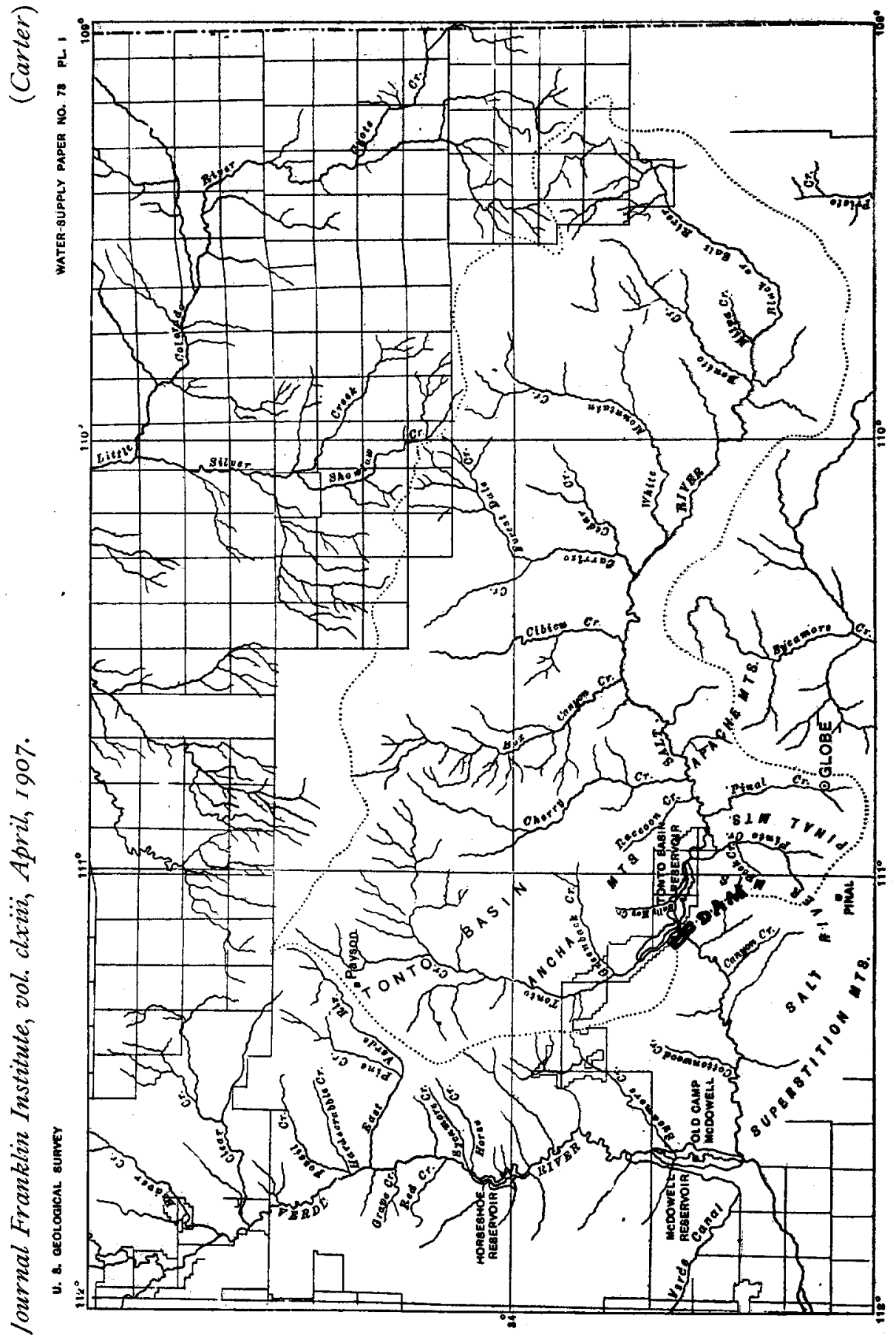


These figures show that irrigation was carried on extensively if not always scientifically before the Government took the matter in charge. The birth of the Government Reclamation Service marks a new dawn in the era of irrigation, because the highest engineering and scientific skill will be brought to bear upon these most stupendous projects which dwarf into insignificance by their immensity, former irrigation projects.

Major J. Wesley Powell was a remarkably well-informed man. After serving as Director of the U. S. Geological Survey for a number of years he was appointed Chief of the Bureau of Ethnology. It is an interesting fact that a number of the leaders of the Bureat of Ethnology to-day were formerly members of the U. S. Geological Survey. The present Chief, Mr Holmes, Dr. Fewkes and $\mathrm{Mr}$ Magee are among the leaders who were formerly geologists. There is little doubt but what their attention was first drawn to ethnology by their investigations in the West and their contact with the various Indian tribes and their familiarity with the various ruins and cliff dwellings. Powell was what might be termed a broad gauge man, while he had the knowledge of the specialist in many cases; his learning was rather of that broad and general character which gives one the power to correlate, classify and utilize scientific knowledge of many subjects. When he was testifying before the Committee on Irrigation of the House of Representatives he made some exceedingly interesting and valuable statements about the destruction of timber in the arid region which are ecrtainly worth repeating. Timber is an exceedingly important, though scarce, production in the arid region and for the Roosevelt dam across the Salt River more than 3,000,000 board feet, 800,000 feet of lumber, and about I, IOO poles have been cut from the Government Reserves on the Sierra Ancha Mountains, where a saw mill was erected, notwithstanding this will be a dam of solid masonry. Powell was asked by the Chairman about the rainfall on the mountains and in the valleys of the arid region. Powell explained to the committee that the rainfall is very irregularly distributed in the arid region. It is concentrated on the mountains and very little falls on the great valleys and plains. It is through the use of these mountain streams that $100,000,000$ acres of land can be irrigated and redeemed, while the rain that falls on the valleys and plains sinks through soil and 
sand and a great deal is lost by evaporation. He then placed $\mathbf{a}$ colored map before the committee which showed the forest areas in the arid region. 'This map was made from surveys carried on and was fairly accurate. These are of two kinds, first, the forests on high mountains and plateaus, which are the forests of commercial value, the pine, fir, spruce and sequoia. The area covered by forests of this class is not one-tenth of the whole; it is about I25,000 square miles, but all are on high mountains and plateaus and are not dense and could stand on one-fourth the space. In addition to these there are forests of some value covering a large area; these are pinion or nut pine, cedars and dwarf oaks. They are available for fire wood, fences and minor purposes. The area covered by these forests is a little over 130,000 square miles, so that within the arid region the extent of forest is about one-fifth and is scattered.

What Powell wanted to point out was the relation of these forests to agriculture and other industries of the country. The lower limit of the commercial forests varies from 4500 feet above the level of the sea at the north to about 6000 or 7000 feet abovetide at the south, and from this lower limit the timber rises 4000 feet into the region above. Where these great commercial forests are, great snow falls occur during the winter and in the summer frosts may be expected, so that by reason of the altitude and temperature the region covered by these commercial forests is not fit for agriculture. The forests are being rapidly destroyed and it is of their protection and relation to agriculture that Powell spoke. The forests are utilized by the people who are engaged in agriculture in the valleys from five to one hundred miles away. They are burned as fire wood and utilized for mining purposes.

Mr. Herbert- "And the railroad companies also use them largely for cross-ties."

Major Powell- "Yes, sir; but ordinarily that is not a very great use. The mining use is great, the domestic use is very great, and the use for railroad purposes is of little importance. A man who cultivates a farm in this region usually has no timber on his tract. The timber with which he builds his house and fences and uses for fire wood grows many miles away. Hence they build roads into the cañon and bring the timber down, and they construct tramways and slides down the mountain sides and flumes, taking it out on streams of water and floating it down. So 
that the timber region is always in another region from the farming industry. But the timber is being rapidly destroyed by fire.

c. S. Reclamation Service.

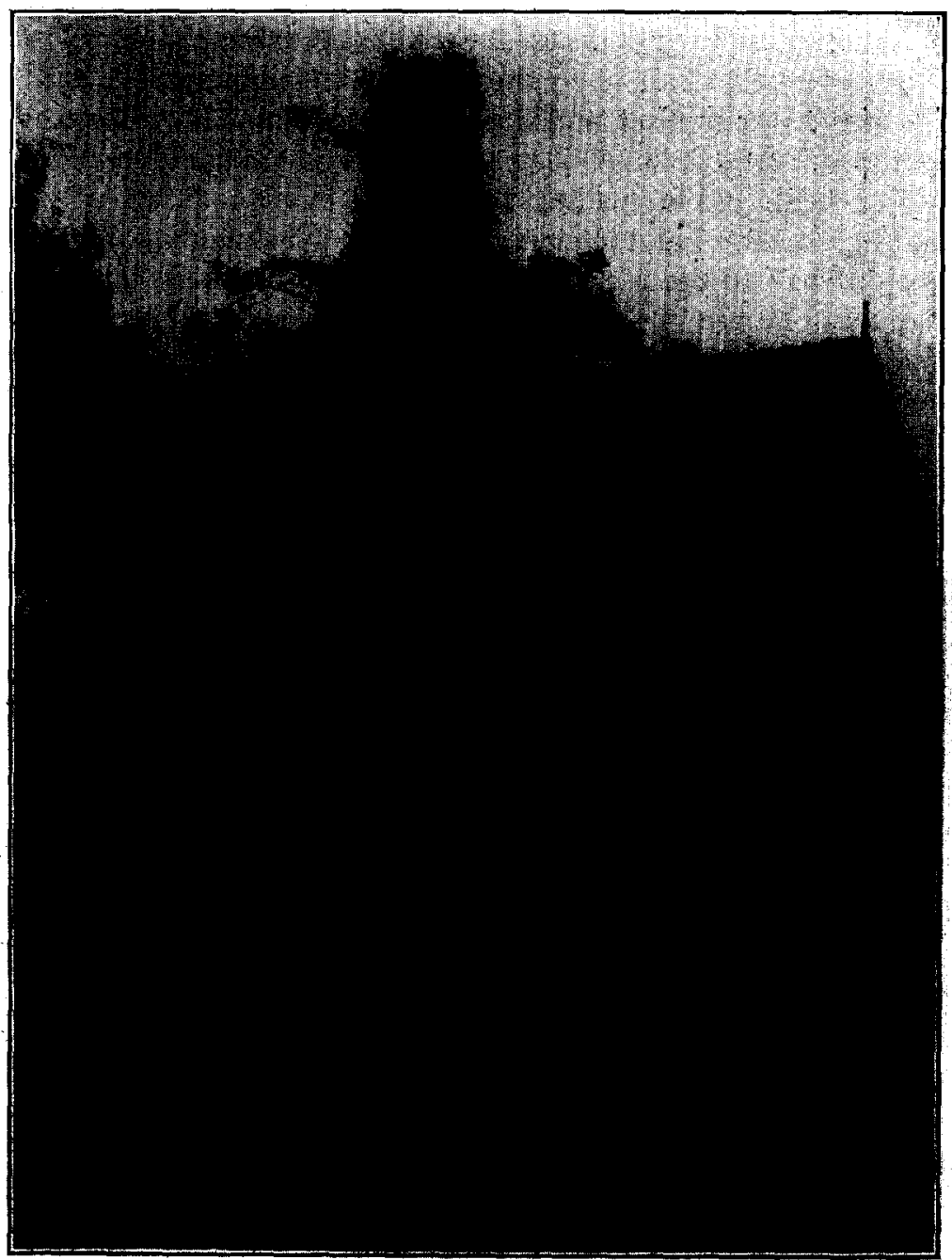

View showing the rank growth of cultivated flowers when watered fraquently. Illustrating how an ordinary cottage can be beautitled in Salt River Valley, Ariz.

That which man uses is insignificant. Man himself, taking the grand aggregate, has made no impression on the forests of that country. They grow faster than man has heretofore cut them 
down, and if they could be protected from devastation by fire the nse made by man would never injure the forests-not until a vastly denser population is gathered. These forests are composed of coniferous trees that are rich in inflammable resinous substances; the bark of trees is exceedingly inflammable and the pine needles that fall upon the ground are inflammable and all give rise to great fires and vast areas of forest have thus been destroyed. A little more than ten years ago I mapped the Territory of Utah and in making that map I delineated not only the existing forests, but the burned forests and found that at that time one-half of the forests of the Territory had been burned. I have seen one fire in Colorado destroy more timber than has been used by man from the migration to Pike's Peak up to the present time; and I have seen several such fires in Colorado. This past season, as an attaché to the Senatorial Committee investigating the question relating to the arid lands, I passed through South Dakota, North Dakota, Montana, Washington, Oregon and Idaho by train. Among the valleys, with mountains on every side, during all that trip a mountain was never seen. This was because the fires in the mountains created such a smoke that the whole country was enveloped by it and hidden from view. That has been the experience for twenty odd years, year by year, in this region. The geographical work of our Survey is cut off during the very dry months by the smoke; the men can not get lines of sight from height to height through that country because of the fires produced in the mountains and the smoke settling down over the land. In the last twenty years one-half of the timber has been burned. Where timber burns in this manner it springs up again; the lands as forest lands are not destroyed by these fires, but the timber itself is destroyed, and it is of slow growth."

Powell testified in I 890 and of course conditions are not now quite the same and the more recent careful surveys might change these estimates somewhat, but as late as the summer of 1905 while stageing a hundred miles through the heart of the Sierras the author saw forest fires that were doing great damage and even impeding travel.

Fifteen years ago there were very few irrigation engineers in this country. Irrigation engineering was just being recognized as a distinct branch and was engaging the attention of some of 
the prominent engineers in the United States. The early stages. in the development of irrigation had about passed and irrigation projects on a large scale were being considered and the construction of permanent and substantial works required a special personal knowledge which could best be gained by visiting a country where irrigation was conducted on a grand scale and where great engineering works of permanent value were constructed. Accordingly Mr. Herbert M. Wilson, C.E., was commissioned to visit British India and confine his observations to those features especially, which will be of greatest importance and benefit to

U.S. Reclamation Service.

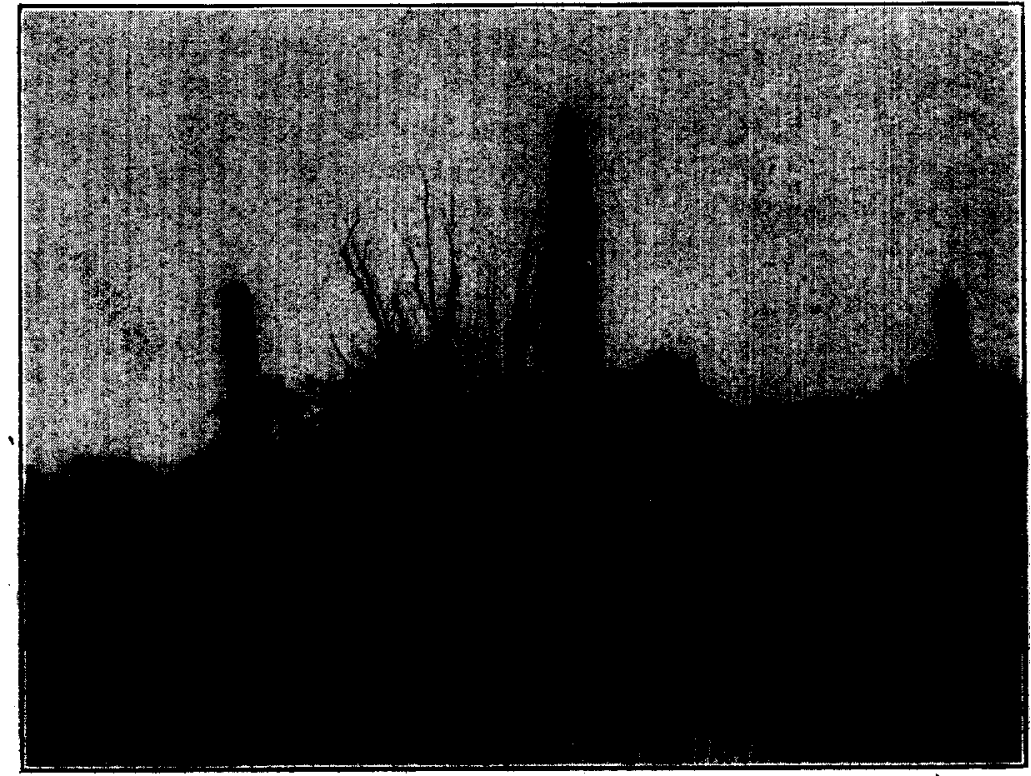

View showing the different varieties of Cactus growth under cultivation at Insane Asylum near Phoenix, Arizona.

those who conduct irrigation on a large scale in the arid and semi-arid regions of the United States rather than to describe works of a novel and astonishing character. There is one rather curious and interesting statement made in the abstract of the Third Annual Report of U. S. Irrigation Survey, I890-I89I. Speaking of Mr. Wilson-"He shows the great benefits financially derived from the canals of India, and points out how in many localities the topography, climate and water supply re- 
semble those of our arid West. Of course with our lower mountain ranges and smaller rivers, Americans cannot construct such great canals, nor are we called upon to build such gigantic structures for the control of water supply, but, on the other hand, the smaller irrigation systems of India serve as a means of comparison and enable us to draw conclusions as to the excellencies or defects of our own methods."

The above statement shows that fifteen years ago such irrigation projects as the Government engineers are working out and finishing to-day were never conceived or even dreamed of as being possible. Mr. Wilson said before his departure he was busily engaged in reading all the books and reports on Indian irrigation procurable, in order to plan the trip so as to see the most in the least space of time. Through the co-operation of the Director of the United States Geological Survey he left Washington in 1889 with a grip full of letters of introduction to various secretaries of public works, departments in India and to consular officers abroad and to prominent English engineers. He made a successful observation journey and examined only the principal canals navigable and non-navigable and neglected the deltaic and inundation canals, as he said there was little or no probability that such works will ever be constructed in the United States. He said: "India stands pre-eminent for her gigantic engineering undertakings. No other country has so vast and so fertile an expanse of territory, with such convenient slopes for the construction of canals, and at the same time such an abundant water supply. In general there is great similarity between the climate and topography of the great northern plains of India and portions of our arid West, especially the eastern slope of the Rocky Mountains and the Great California Valley. Central India and the Deccan have many features in common with the central arid Territories, particularly portions of Northern Arizona and Southern Utah. The climate is as similar to that of our central Territories as is the topography. The average annual precipitation rarely exceeds thirty inches, while the precipitation during the autumn crop varies between two and six inches. The topography of the upper Mutha Valley seemed very familiar. Had I been suddenly transported in my sleep to Northeastern Arizona the similarity of the topography of the two regions could not have more strikingly impressed me. At Lake Fife the Mutha 
River makes its exit through a narrow cañon similar to those of the mesa country in Northern New Mexico and Arizona and the cliffs are similar in their abruptness and sharpness of outline to the mesa cliffs of our Southwest. Wherever the soil is uncultivated it is covered with a low scrubby grass dried and parched by the sun. At the canal edge the barren slopes are suddenly merged into endless green and well cultivated fields. The slopes of the hills are rocky and barren, covered. with a growth of low trees among which babul or mesquite is the most prominent."

One recognizes in the above description a kind of topography

U.S. Reclamation Service.

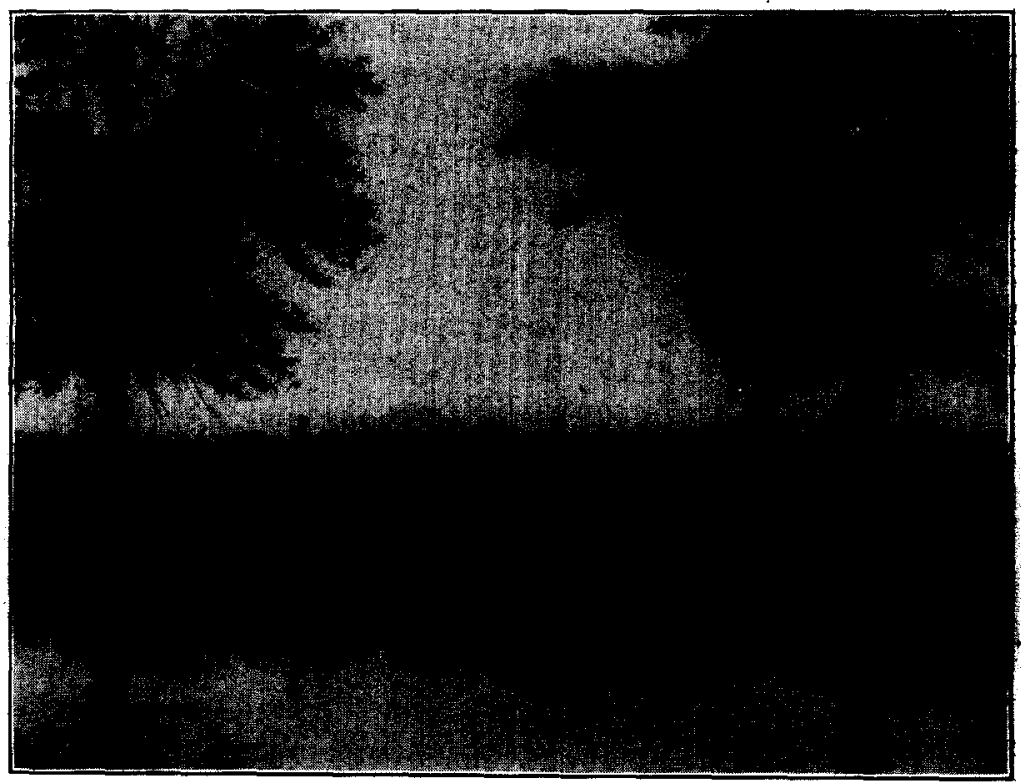

Fxcellent pasture in Salt River Valley. The Result of Irrigation.

which is common in the arid Southwest, although the rainfall is much less with us. The Gila River is the principal stream in Southern Arizona. It empties into the Colorado River near the town of Yuma. Its principal tributary is the Salt River, which lies south of the center. The Upper Salt drains that portion of the territory east of the center. The largest tributary of the Salt. River is the Verde which drains the central part of Arizona. The Salt River brings more water to the main trunk of the Gila 
than the Gila carries before they join. This is due to the fact that the Salt River rises in the mountains, and the peaks from I0,O00 to I I,OOO feet are high enough to get a generous rainfall. The Salt River drains a mountainous country east of where the Verde joins it. There is another tributary east of this called the Tonto Creek. A half a mile below this stream the river enters a great cañon with precipitous walls and a narrow bottom. In this cañon is located the great Roosevelt dam of the Salt River.

Mr. A. P. Davis in Irrigation Paper 73 advances another reason why there is more rainfall southwest of the Colorado Platean in Arizona than there is on the plateau- "Another partial explanation is found in the meteorological condition. The moisture of this region is brought from the Pacific Ocean and the Gulf of California by the prevailing southwest wind. As this wind ascends the elevations toward the Colorado Plateau its temperature is lowered which reduces its capacity for holding moisture and increases its relative humidity. When this quantity reaches IOO per cent. in any part, precipitation occurs. This influence continues until the wind passes the summit where the process is reversed. Therefore, the hydrographic resources of the country immediately southwest of the Colorado Plateau is disproportionately great when compared with those to the northward. For instance, the precipitation at Fort Apache, as shown by a mean of twenty years observations, is $19 \frac{3}{4}$ inches, the elevation being 5,050 feet, while the precipitation at Holbrook, at an elevation of 5,047 feet, on the northern slope, is 8.47 inches, as indicated by a mean of ten years observations. This is an important fact especially when taken in connection with the fact that the great areas of valley land with a semi-tropic climate lie in the southwestern portion of the Territory, and are easily covered by the streams which are formed by the conditions above described. and which constitute the main features of the great Gila River system."

The following extracts, quJtations and general information pertaining to the Roosevelt dam and its construction are taken from Irrigation Paper No. 73 by A. P. Davis: In the deep cañon where the dam is being built a great deal of silt had accumulated and borings to bed rock were made at thirty-one points in the cañon. In the upper end they found from 44 to 64 feet of river silt. The dam of course must be built on soiid rock, 
so more than a quarter of a mile farther down the cañon they found by boring a favorable site where the river silt was less than half the above amount. He says: "The gorge on Salt River is an especially favorable site for a masonry dam, and the most permanent, conservative and secure form of high dam that is known to engineering science can be constructed. The formation is sedimentary, with the strata inclined at an angle of about $30^{\circ}$ to the horizon dipping toward the reservoir, a most favorable

Water Supply F aper 72.

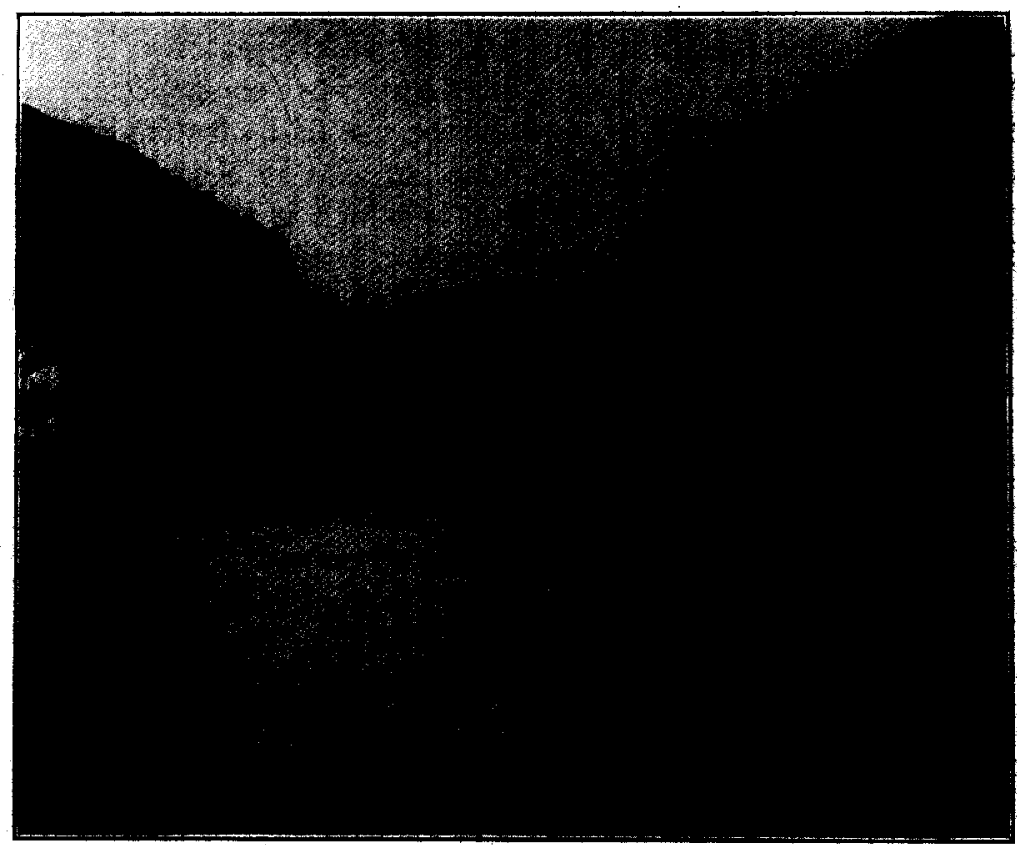

Salt River Dam site Looking Downstream.

condition for retaining stored waters and for the stability of the dam. The foundation and abutment of hard, tough, fine grained sandstone are all that could be desired. Building stone of the same material is at hand above the site. Good Portland cement can be made in the vicinity. Sand for mortar can be obtained from the river bed, but will have to be washed and screened, and it is thought that the best plan will be to manufacture sand by crushing quartzite, which occurs in abundance near the site. This will provide an ideal sand, and as power is abundạnt its cost will 
not be great. The dam must be so designed and constructed as to be safe from destruction by any or all of the forces acting upon it. It is possible for a masonry dam to fail in any one of three ways: I. By overturning; 2, by sliding on the base, or on, any horizontal joint; 3 , by crushing its foundation or masonry near the base. A factor of safety of at least two is secured against overturning by so designing the dam that under all conditions the resultant of all the forces acting will fall within the middle third of any horizontal joint. This also eliminates the possibility of any tensile strains in the masonry, a very desirable result. The same condition also secures safety against sliding. which is insured in a still greater degree by constructing the masonry of random rubble, and by the use of hydraulic mortar, bonding it together and to its base, so that it becomes a true monolith-a part of the solid rock to which it is firmly joined. Under these conditions a large margin of safety is provided, as the structure cannot slide without shearing the masonry. In addition to these precautions the dam planned is to be built in the form of a circular arch, greatly increasing its safety against both sliding and overturning. In fact neither can occur without overcoming the gravity and cohesion of the masonry, and also crushing the masonry or abitments. The total factor of safety against failure by the first and second methods can not be exactly known, but it is unquestionably very great. The recorded failures of high masonry dams are as follows: At the Habra dam in Algiers poor hydraulic lime was used, and a red earth with a large percentage of clay was used in the mortar instead of sand. This combination made a poor mortar, and the rock was also poor, being a porous calcareous grit. It is supposed that the failure occurred by the crushing of the foundation under a computed stress of 13.3 tons per square foot. At the Bouzy dam in France the foundation was fissured and permeable and not on solid rock, allowing an immense upward hydrostatic pressure; the section was so light as to permit great tension in the masonry in the back. It was straight in plan, and when the reservoir was nearly filled the central portion of the wall was shoved forward about a foot, causing ruptures and leakage. This was afterwards repaired and the foundation reinforced. Six years later when the reservoir was full the dam suddenly overturned at a plane about 33 feet below the top. The above recited defects were the un- 
doubted cause. At the Puentes dam in Spain the central portion of the dam was founded upon piles driven in earth. When the rising water applied a heavy hydrostatic pressure, this portion of the foundation suddenly gave way and left the top and ends of the dam standing in the form of an arched bridge.

"The dam at Austin, Texas, was an overflow dam built of limestone rubble, the stone being very soft and of poor quality. The foundation was on a geological fault and was of soft lime-

Water Supply Paper 73

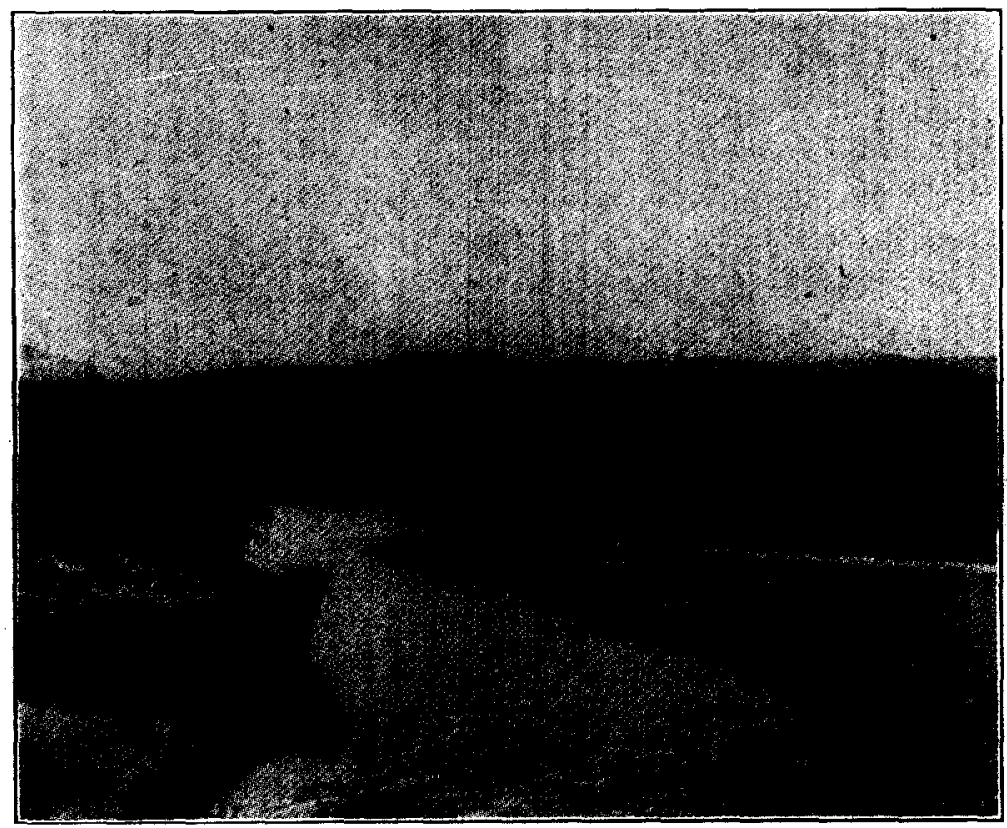

Salt River Reservoir Site Looking Upstream.

stone, in thin horizontal layers, which had little adhesion and probably very little friction upon one another, and the failure, which was by sliding, is supposed to be due to this fact.

"In all four of the above cases the foundation was defective. In three the stone was poor and in two the mortar was poor. All were straight in plan except the Puentes, which was polygonal in plan and arched up stream. This dam seems to have been very well planned and constructed except for one fatal defect of being founded on piles instead of solid rock. All of the defects in 
these failures can easily be avoided in the proposed dam by a reasonable application of care and skill. The proposed dam is designed to be 217 feet above low water in the river at the dam site and to store water at a maximum depth of 190 feet. The total height of the dam above lowest foundation will be about 247 feet."

Since Mr. Davis' report was written the dimensions of the Roosevelt dam have been increased (see 4th Annual Report Reclamation Service.)

Length of dam at datum.............. 2 ro feet Height of spillway above mean low water........ 220 feet Height of roadway above mean low water......... 240 feet Total height of dam from foundation to parapet..... 285 feet

This dam will back the water up Salt River about 16 miles and up the Tonto Creek nearly as far. It will produce a lake over 25 miles long and from one to two miles wide The reservoir will have a capacity greater than that of any other artificial reservoir in the world.

Spillways 20 feet deep will be excavated in the solid rock sides of the cañon and the rock used in the construction of the dam.

The location lends. itself admirably to a curved form of dam, this form containing but little more material than a straight one of the same section. The proposed structure is to be built on a circular curve, convex up stream, the back having a radius of 400 feet and the face a shorter radius from the same center. The dam is to be of uncoursed rubble masonry and to have a section on modern conservative ideas as a simple gravity structure, and the added stability due to its curved form will greatly increase its factor of safety. The rock of which the dam will be constructed will be excavated from the spillways and is a tough, close-grained sandstone. Two cubes with edges of two inches were cut from samples of the rock to be used in Salt River dam and crushed in the testing machine at the United States Navy Yard at Washington. Sample No I crushed at 59,650 pounds, being I 4,9 I2 pounds per square inch or I,O74 tons per square foot. Sample No. 2 crushed at 100,000 pounds, this being 1,800 tons per square, foot. These results are so high that the strength of the rock is entirely eliminated from the discussion. The rock is to be used in as large pieces as practicable, in crder to make the number of 
joints as few and the quantity of mortar as small as may be. It is estimated that rock will cccupy 70 per cent. of the structure: Fifteen per cent. will consist of cement mortar in which the stones are bedded and fifteen per cent. will consist of cement concrete rammed into vertical joints. Taking the weight of the mortar as I I 5 pounds per cubic foot and that of the concrete as I 30 pounds, the masonry will weigh as nearly as can be estimated 146

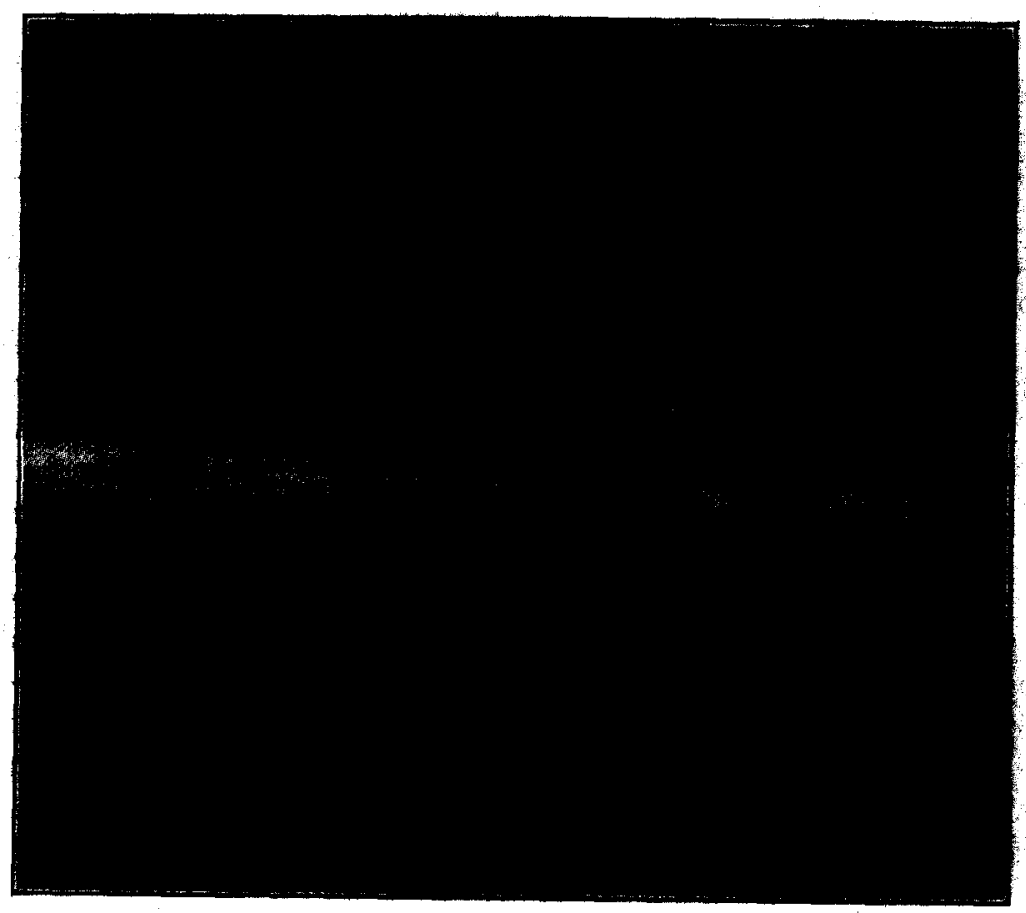

Drilling party on Salt River. ILine A of Borings.

pounds per cubic foot. On this estimate the strains have been computed and the section of the dam designed. As the dam is to serve as a highway, a top width of sixteen feet has been adopted with parapets along the sides. The pressure on the top when the reservoir is full will be I 5.9 tons per square foot, computed on the assumption that the dam is a rigid-monolith and non-elastic. 


\section{Specifications in Brief for the Construction of the Dam.}

Diversion of the River.-The diversion of the river will be accomplished by means of sheet piling driven as deeply as practicable directly across the cañon, beginning at south side and reaching as nearly as practicable to bed rock, the piling to be reenforced at and above the surface by a heavy wall of sand and gravel excavated from the site of the dam, the water to be diverted through the outlet tunnel which will be constructed in advance.

Foundation.-All earth, sand, gravel and boulders, disintegrated loose and seamed rock will be excavated and removed from the entire area of the base of the dam in order to secure a firm foundation on solid rock. Explosives shall not be used in excavating the rock unless absolutely necessary, and then only in small quantities in shallow holes to avoid fracture of the rock forming the foundation of the dam.

Masonry.-The main body of the dam shall be constructed of broken range cyclopean rubble. The stone shall be quarried from the walls on each side of the cañon. If sufficient quantity of hard fine grained stone cannot be obtained in these spillways it shall be quarried elsewhere. All stone shall be washed and laid in Portland cement mortar. No mortar joint in the face shall exceed one inch in thickness. The body of the dam shall be composed of as large stone as practicable, well shaped and laid so as to break joints and bond in all directions. Vertical joints between the stones must be nowhere less than four inches and must be filled and rammed with Portland cement concrete. The aim shall be to use the largest proportion of stone and the smallest proportion of mortar and concrete. Facilities shall be provided for handling stones weighing twelve tons, and large stones shall be tused as far as practicable.

Mortar and Concrete.-All mortar used in the lower thirty feet of the dam shall consist of I part of Portland cement, 2 parts of good sharp sand; and all concrete used in this portion of the dam shall consist of I part cement, 2 parts sand and 3 parts of broken stone as will pass through a screen with meshes 2 inches square. The mortar and concrete used in the upstream face of the dam for a thickness of 20 feet shall be of the quality above specified. In all parts of the dam which are more than 20 feet from the up- 
stream face and 30 feet from the base the mortar shall be I part Portland cement, 3 parts sand, and the concrete one part Portland cement, 3 parts sand and 4 parts broken stone of a size to pass through a screen with meshes 2 inches square. All mortar and concrete shall be thoroughly mixed and used so promptly that there will be no danger whatever of incipient setting of the cement previous to the completion of the masonry in which it is placed. No cement shall be used until at least sixty days after its manufacture and not until it shall show satisfactory tests according to chemical and physical requirements adopted by the Ameri-

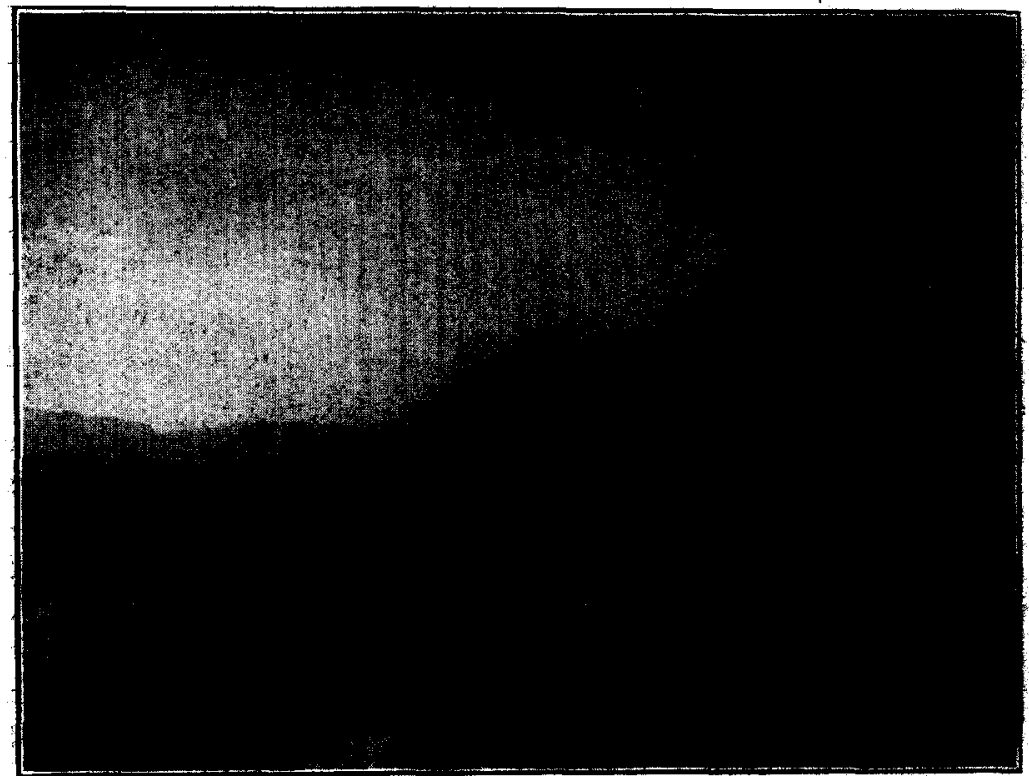

Government Road Salt River Project Ariz. Just over Roosevelt Dam site.

can Society of Cjvil Engineers. The reason for using a larger percentage of cement in the base of the dam is that here will be the greatest pressure, and the higher percentage of cement will give a greater power of resistance to crushing. The higher percentage of cement is maintained on the water face of the dam all the way to the top in order to render it as nearly impervious as possible. It may be confidently predicted that a masonry dam at the proposed site, constructed on the above plans and specifica- 
tions, would be absolutely permanent, safe, solid, and secure for all ages to come, as truly as the everlasting hills, of which it will become an integral part."

\section{SEDIMENT.}

Mr. Davis also states that "most of the streams of the Southwest carry considerable solid matter which causes annoyance in canals and has a tendency to fill any reservoir constructed on the stream. This is true of the Rio Grande, Colorado, Pecos, and Gila Rivers. There is silt also in the waters of the Salt River as shown by its occurrence in the canals, but it is not nearly as abundant as in the streams above mentioned. The basin tributary to the Salt River reservoir lies in large part in high timbered country and includes the Apache Indian Reservation. The reservation is almost entirely covered with forest and grass. The Tonto Creek and a few other tributaries deliver some silt during floods. From observations of the amount of sediment carried he found the amount so small as to be almost negligible, but the discharge during the year was far below the normal. It would probably be Ioo years before the loss of storage capacity would be seriously felt and it would be necessary to resort to methods of clearing it ont. The greatest amount of sediment will usually be found in the lower layers of water and it will therefore contribute to the maintenance of the storage capacity to drain all the waters. from the lowest possible point at all times. Two outlets are provided in the form of tunnels Io by I 3 feet, one around each end of the dam. Whenever water begins to run over the spillway the gates must be opened to full capacity not only to draw off the maximum quantity of sediment but to reinforce the spillway. The plan adopted then to facilitate the discharge of sediment and reinforce the spillways is to draw all water from the reservoir through large openings directly on the bottom. The two tunnels will be dug through the solid rock, one on each side of the cañon."

\section{POWER PLANT.}

He further says: "In the construction of a great dam one of the most important elements is that of power. This is necessary on a large scale for drilling purposes, for handling rock, for mixing and handling mortar and for crushing rock to be used in concrete. In the present case it has been found possible and very de- 
sirable to manufacture on the ground the large quantity of cement required in the dam. This would require about 300 horse-power day and night for grinding rock and clinker and for handling materials and running machinery. It is usual to provide such power by means of steam engines, but in the present case this is rendered very expensive by the scarcity of fuel. Coal in quantities, now costs \$Io per ton in Globe, and the wagon haul to the dam site would nearly double this. A limited amount of

U. S. Reclamation Service.

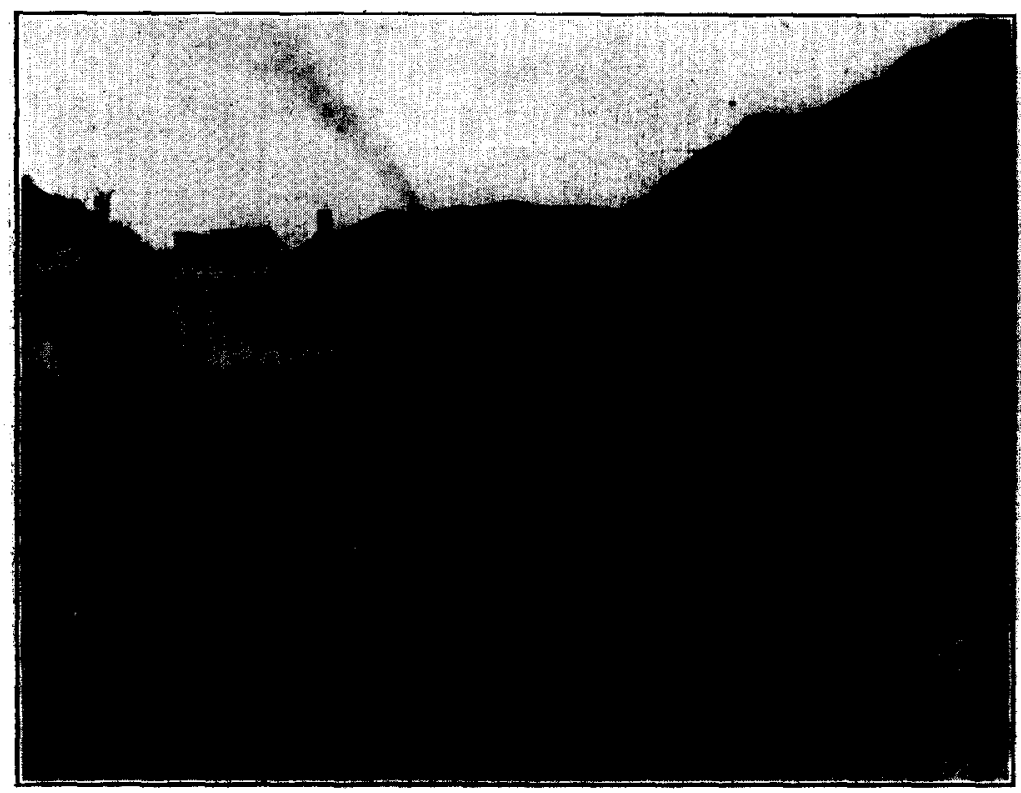

Detailed view of the Cement Works, Roosevelt Dam.

wood is available, but to secure the large quantity which would be required if it were the sole dependence for power would involve a long haul. The best means for providing the necessary power is by the development of water power on the river. This will involve the construction of a diversion dam and canal, which can afterwards be utilized if required for sluicing accumulated silt out of the reservoir. The power developed can be used in the neighboring mines or in the valley below for pumping purposes. The proposed canal would head some distance above the reser- 
voir, follow above its water line, and finally discfrarge just below the dam, with an available head of about 180 feet. It is designed to deliver Ioo cubic feet per second, and to develop a net energy of about 1200 horse-power after deducting seepage, friction, and the losses in water wheels, electric plant, etc. It is designed to use 900 horse-power at the dam and 300 horse-power at the cement mill. The power plant will consist of three units of 300 kilowatts each."

Since Mr. Davis' report changes were necessarily made in the canal and power plant (see $4^{\text {th }}$ Annual Report Reclamation Service.) The canal will be 19 miles long and have a capacity of 200 second feet. The water will be carried above the reservoir to a point below the dam and there discharged through turbine wheels under a head of 220 feet, developing 4400 horse-power, to be used in constructing the dam and pumping water for irrigation in Salt River Valley. The water wheels and dynamos were increased.

\section{CEMENT MANUFACTURE.}

The problem of furnishing cement at a reasonable expense was an extremely serious one. It is an isolated locality and there is a wagon haul of 40 miles over exceedingly rough and mountainous country to the nearest railroad, which is a branch road with light traffic and high rates. It was estimated that cement would cost at the dam about $\$ 9$ per barrel, and as later calculations. showed that at least 220,000 barrels of cement would be required in the construction, the total cost was prohibitive. It was finally decided to make a careful search in the vicinity for the rocks out of which cement is made, namely-limestone, clay or shale, and if found in abundance and right composition for the manufacture of cement then a cement plant could be erected and the problem solved. With this end in view search was made in the Tonto basin for limestone, clay and shale. Eight samples in all were sent in for analysis to the superintendent of the cement works at Colton, California. Samples I and $y$ seemed to be the most satisfactory. No. I was a limestone near the dam site, very abundant and convenient. The analysis showed:

Alumina and ferric oxide......................... 0.20

Magnesia $\ldots \ldots \ldots \ldots \ldots \ldots \ldots \ldots \ldots \ldots \ldots \ldots \ldots \ldots \ldots .6 \ldots$ 
Calcium carbonate................................95.80

Insoluble residue $\ldots \ldots \ldots \ldots \ldots \ldots \ldots \ldots \ldots \ldots \ldots \ldots, 3.30$

99.90

No. 7 was a clay from the hills 3 miles north of the dam site, very abundant. The analysis of the clay showed:

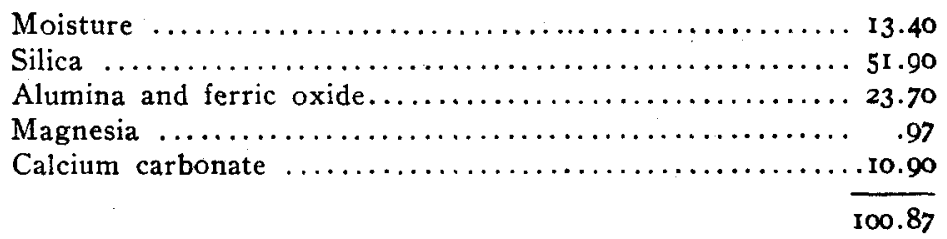

The shales that they found were expensive to quarry and grind, so they were discarded as they would only have been used if no suitable clays were found. All shales were once mud or clay laid down in ancient seas or lakes, and when the water disappeared pressure consolidated the mud or clay into shale. Samples of the limestone and clay were sent to Mr. E. A. Duryee, superintendent of the cement works, for an experimental burn. He reported as follows: "The clay and limestone were ground separately and then mixed in the proportions of 6.18 pounds of limestone and 2.25 pounds of clay, making a raw mixture that tested 43 per cent. lime. As the limestone was very hard and therefore more difficult to make into cement than a softer material, fluor spar to the amount of $\mathrm{I} \frac{1}{2}$ ounces or I per cent. was added. The materials were also ground quite fine, but no finer than is the practice in some cement works. The raw mixture was made into briquets and these after being dried were burned in a gasoline furnace. They burned to a good hard clinker of a good color.

ANALYSIS OF CEMENT.

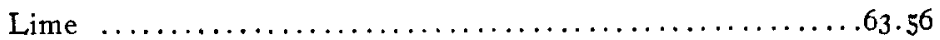

Alumina and ferric oxide..........................

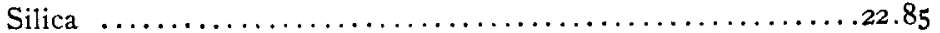

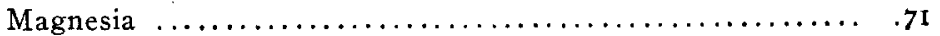

Alkalies not determined.

TENSILE STRENGTH OF NEAT CEMENT BRIQUETS.

ths. per sq. inch

7 days ( 1 day in air, 6 in water) $\ldots \ldots \ldots \ldots \ldots \ldots \ldots \ldots \ldots+4$ Io

I4 days ( $I$ day in air, then in water until broken)..........690

28 days ( $\mathrm{I}$ day in air, then in water until broken)...........775 
These results proved that an excellent quality of cement could be made on the ground. Mr. A. P. Davis states: "The greatest difficulty is the scarcity of fuel. There is considerable wood in the reservoir site, mainly cottonwood and mesquite, which it will be desirable to clear out of the reservoir in any event. Wood is not suitable for burning cement clinker by modern methods, but if made into charcoal and then ground to powder would answer, or oil may be imported for the purpose from California. A large amount of power is required for grinding the rock and the clinker and a still larger amount will be necessary in the construction of the dam, for excavating to foundation, quarrying and handling the rock, mixing and handling the mortar, etc. If steam power were used for all these purposes the small amount of wood at hand would soon be exhausted and it would be necessary to haul wood a long distance or to import coal, either of which would be very expensive. Water power can be developed by diverting water from Salt River above the reservoir site, carrying it in a canal above the proposed lake and dropping it through a penstock just below the dam. By such means an ample supply of power can be obtained, available through the construction period and afterwards also if desired."

"The estimated cost of the cement plant, with modern machinery, capable of producing 300 barrels per day, as furnished by Mr. E. A. Duryee, is \$9I,ooo. With such a mill using charcoal for burning cement the cost of manufacture would be approximately $\$ 2$ per barrel. It was finally determined to burn the cement with crude California petroleum. Eleven gallons are required to burn a barrel of cement. The contrât price was $\$ 3.48$ per barrel, delivered at the cement mill in quantities of 3000 barrels monthly. The oil is hauled by rail from California to Mesa, Arizona, thence by traction engine 24 miles and by mule teams 37 miles to Roosevelt. (See 4 th Report Reclamation Service.) The road from Globe to Payson passes through the reservoir almost its entire length. In case of the construction of the dam this road would be submerged and it will be necessary to provide a new one around the reservoir. If it were deflected to the east it would be thrown into an exceedingly rough mountain country, where the construction would be very expensive and the road beset by heavy grades. By passing to the west of the reservoir it would be necessary to use the dam as a viaduct and to 
build bridges across the spillways. There would not be a great amount of road constructed and this plan would be far cheaper and furnish a much better road than could be built east of the reservoir."

Twenty miles of road were after ward built to connect Globe with the dam site. Altogether it has been necessary to construct I 10 miles of road, part of which replace roads that will be flooded by the reservoir.

In January, ı906, the Reclamation Service issued the following statement for the public:

\section{ARIZONA: SALT RIVER PROJECT.}

This project contemplates the construction of a large storage dam at Roosevelt, Ariz., 27o feet in height, which will regulate the supply of water from gravity systems for about 160,000 acres of land in the vicinity of Phœnix. When the dam is constructed there will be developed a large amount of power which will be utilized to increase the water supply in the Salt River Valley by means of pumping from underground sources. Early in 1904 contracts were awarded for the construction of considerable auxiliary work, power canals, sluicing tunnels, etc. A cement mill was erected by the Government and is now in operation, furnishing a first-class quality of cement to be used in the works. The construction of the dam will require 220,000 barrels of cement. The excavation for the power canals is completed, the lining of canals is nearly completed, and the work on the sluicing tunnel was finished Oct. 3 rd, 1905. The contract for the construction of the large dam was awarded to J. M. O'Rourke \& Co., of Galveston, Texas. It is understood that there are no public lands available under this project for homestead entry, the entire area having been filed upon by settlers, many of whom have gained title to the land. For information as to the possibility of acquiring lands by purchase from present owners, and other data of a local character concerning the soil and climate of the valley, apply to Mr. B. A. Fowler, President of the Salt River Valley Water Users' Association, Phœnix, Ariz. The irrigable lands under this project are tributary to branch lines of the Southern Pacific and Santa Fe Railroad systems. 